\title{
Research Paper \\ Epidemiology and Death Trends Due to Diabetes in Iran
}

\author{
Elnaz Jafarvand ${ }^{1} \mathbb{O}^{\circ},{ }^{*}$ Amin Ataey $^{2}$ (ㅇ, Sare Edalati ${ }^{3}$ (i) \\ 1. Department of Community Nutrition, School of Nutritional Sciences and Dietetics, Tehran University of Medical Sciences, Tehran, Iran. \\ 2. Department of Health Economics and Statistics, Deputy for Public Health, Ministry of Health and Medical Education, Tehran, Iran. \\ 3. Department of Community Nutrition, National Nutrition and Food Technology Research Institute, Faculty of Nutrition Sciences and Food Technology, Shahid \\ Beheshti University of Medical Sciences, Tehran, Iran.
}

\begin{tabular}{|c|c|}
\hline $\begin{array}{l}\text { Use your device to scan } \\
\text { and read the article online }\end{array}$ & \\
\hline 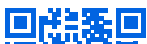 & Cltat on Jafarvand E, Ataey A, Edalati S. [Epidemiology and Death Trends Due to Diabetes in Iran (Persian)]. Quarterly of "The \\
\hline  & Horizon of Medical Sciences". 2021; 27(2):198-213. https://doi.org/10.32598/hms.27.2.2764.1 \\
\hline 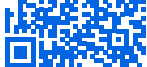 & dol'https://doi.org/10.32598/hms.27.2.2764.1 \\
\hline
\end{tabular}

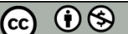

Received: 27 Dec 2019 Accepted: 05 Sep 2020 Available Online: $01 \mathrm{Apr} 2021$

Keywords: Mortality; Diabetes; Iran; Epidemiology

\section{ABSTRACT}

Aims Diabetes mortality undergoes a growing trend worldwide that results in reducing life expectancy in society. Diabetes has been a significant health challenge in recent decades and imposed a lot of economic burden on the community. The present study aimed to evaluate the trend of diabetes mortality in Iran over five years.

Methods \& Materials The mortality data published by the Ministry of Health and Medical Education has been used in this analytical cross-sectional study. The number and rate of diabetic cases are specified based on age, gender, location, and the death process from 2006 to 2010.

Findings About $54.9 \%$ and $45.1 \%$ of the deaths occurred in women and men, respectively, with a male to female ratio of 0.82 . The highest death rate was observed in individuals aged above 70 and 50-69 years with an average age of 68.1 years. A higher mortality rate was observed in the cities than in the countryside, and $40 \%$ of deaths occurred due to non-insulin-dependent (type II) diabetes mellitus.

Conclusion Diabetes mortality has increased from 2006 to 2010 . Higher deaths were observed in women and cities. Considering the increasing population of older adults in Iran, diabetes prevention and control interventions can be carried out through screening, planning, and education.

\section{English Version}

\section{Introduction}

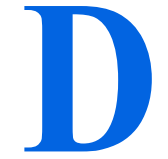

iabetes is a metabolic disease with multifactorial etiology characterized by chronic hyperglycemia caused by impaired insulin secretion or its function [1]. Diabetes is one of the health challenges of recent decades that imposes a tremendous economic burden on society [2]. The World Health Organization (WHO) has declared diabetes a latent epidemic because of the growing number of diabetic people worldwide. It has called on all countries to fight the epidemic since 1993. Based on WHO estimation, the number of people with diabetes will reach from 135 million in 1995 to 300 million in 2025. This increase will be equal to $170 \%$ in developing countries and $42 \%$ in developed countries [3]. Diabetes is also expected to increase in the elderly in developed countries and people of working age in developing countries [4]. Therefore, although diabetes is considered a problem in developed countries, its impact in reducing life expectancy is greater in developing countries [5]. Experts believe that the recent prevalence of diabetes in society is not explicitly related to changes in the genetic and ethnic characteristics of a society but in the lifestyle and modernization of society. Chang-

\footnotetext{
*Corresponding Author:
}

Amin Ataey, MSc.

Address: Department of Health Economics and Statistics, Deputy for Public Health, Ministry of Health and Medical Education, Tehran, Iran

Tel: +98 (21) 81455935

E-mail: ataey5143@gmail.com 
ing the lifestyle can increase the prevalence of diabetes in people with a similar genetic predisposition to diabetes [6].

Three in four (79\%) of people with diabetes live in low and middle-income countries [1]. Diabetes is the seventh leading cause of death in the United States and has always been one of the top ten leading causes of death in Iran [7]. In a study in six countries, including Bahrain, South Korea, and Armenia, the death rate from diabetes increased from 1985 to 2010 by an average of $3.2 \%$ per year [8]. Besides, the number and causes of death are vital to diagnosing society's health status, and death data in different age and gender groups can indicate how the economic conditions prevail in society. Also, the effectiveness of health care programs and intervention programs to promote health is known with changes in mortality rates [9]. The use of such data plays an essential role in monitoring health programs, allocating resources, prioritizing intervention programs, setting epidemiological research priorities, establishing health policies, and conducting medical research [10]. Therefore, in this study, we intend to examine the diabetes mortality rate in Iran from 2006 to 2010 and its five-year trend.

\section{Materials and Methods}

This analytic cross-sectional study was performed using mortality data in Iran from 2006 to 2010 published by the Ministry of Health [11]. Data were collected through various sources such as the Civil Registry Office, cemeteries, hospitals, and health houses by the Information and Applied Research Center of the Ministry of Health and Medical Education. In the next step, the data were integrated with the Ministry of Health and Medical Education. In this study, the mortality rate of different types of diabetes was categorized based on the International Coding of Diseases (ICD-10, code E10-E14) in Iran (all provinces) from 2006 to 2010. The number and rate of deaths from diabetes, male to female sex ratio, and death rates in age and sex groups and their residence were calculated and reported using Excel 2016 software. Also, for data analysis, the Chi-square test was performed in SPSS V. 24. P values less than 0.05 were considered statistically significant. Finally, a picture of the changes in diabetes mortality in Iran over five years was obtained.

\section{Results}

In this study, the mortality of different types of diabetes from all age groups has been collected from 2006 to 2010 . During the study period, 27418 deaths occurred due to various types of diabetes, of whom $54.9 \%$ were females and $45.1 \%$ males. The lowest death rate of both sexes was 9.42 per 100000 in 2006, and the highest was 10.6 per 100000 in 2010. However, in the whole study period, females' death rate was higher than males, and the sex ratio of males to females varied from 0.74 in 2008 to 0.88 in 2006 . In terms of residence, the death rate from various types of diabetes was much higher in urban areas than in rural areas in all years. The average age of the deceased varied from 66.6 years in 2010 to 69.3 years in 2007 and was 68.1 years in total for five years study period. The mortality rate due to diabetes was significantly different between men and women in all years. Diabetes mortality was significantly higher in women $(\mathrm{P}<0.01)$. Also, there was a significant difference in the number of deaths from diabetes between the years of study $(\mathrm{P}<0.01)$. It has increased over the years of study (Table 1 and Figure 1).

Table 2 presents that the lowest death rate from various types of diabetes belongs to the 5-14 years age group (from 0.14 in 2007 to 0.24 per 100000 population in 2010). In comparison, the highest rate belonged to the age group of

Table 1. Number and rate of deaths due to diabetes per 100000 population by sex and place of residence

\begin{tabular}{|c|c|c|c|c|c|c|c|c|c|c|}
\hline \multirow{2}{*}{ Year } & \multicolumn{3}{|c|}{ No. (\%) } & \multicolumn{3}{|c|}{ The Rate per 100000} & \multirow{2}{*}{$\begin{array}{c}\text { Sex Ratio } \\
\text { (Male/Female) }\end{array}$} & \multicolumn{2}{|c|}{$\begin{array}{c}\text { Residence } \\
\text { (Rate per 100000) }\end{array}$} & \multirow{2}{*}{$\begin{array}{l}\text { Average Age } \\
\text { (Years) }\end{array}$} \\
\hline & Female & Male & Total & Female & Male & Total & & Village & City & \\
\hline 2006 & $2858(53.2)$ & $2517(46.8)$ & 5375 & 10.17 & 8.69 & 9.42 & 0.88 & 5.91 & 10.07 & 67.7 \\
\hline 2007 & $2920(54.6)$ & $2432(45.4)$ & 5352 & 11.15 & 9.05 & 10.09 & 0.83 & 6.32 & 11.03 & 69.3 \\
\hline 2008 & $3163(57.3)$ & $2354(42.7)$ & 5517 & 11.94 & 8.66 & 10.03 & 0.74 & 6.31 & 11.41 & 68.8 \\
\hline 2009 & $2898(54.4)$ & $2428(45.6)$ & 5326 & 10.79 & 8.82 & 9.79 & 0.84 & 6.63 & 10.6 & 68 \\
\hline 2010 & $3214(55)$ & $2634(45)$ & 5848 & 11.78 & 9.44 & 10.6 & 0.82 & 6.93 & 11.6 & 66.6 \\
\hline Total & $15053(54.9)$ & $12365(45.1)$ & 27418 & & & & 0.82 & & & 68.1 \\
\hline
\end{tabular}


over 70 years (from 150.69 in 2006 to 181.31 per 100000 population in 2010). The trend of diabetes mortality from 2006 to 2010 by age groups shows that after the age group under 5 years, a relative decrease in death rate was observed in the age group of 5 to 14 and then the trend of diabetes death increased with age and in the age group of 70 years and above has had a vertical ascent (Figure 2).

Regarding the mortality from diabetes by type, the highest cause of death belonged to non-insulin-dependent diabetes (E11), with $40 \%$ of the total number of deaths, followed by other disorders related to diabetes (E12-E14) with 30.8\%. The lowest number belonged to insulin-dependent diabetes (E10), with $29.2 \%$ of all deaths. Mortality is higher in women in all types of death causes (Table 3).

\section{Discussion}

The present study results in a five-year period show that the death rate due to diabetes increases significantly during the study years. This finding is consistent with the results of previous studies on the increase in deaths due to diabetes in all countries, especially developing countries $[4,12]$. The mortality rate due to diabetes in Europe varies from 7.9 per 100,000 people in Greece to 32.2 in Italy. The mortality rate in Iran is higher than in Greece and lower than in Italy. While a declining trend is reported for some non-communicable diseases globally [13], diabetes is an exception. The mortality rate from diabetes is increasing in Europe [14], which is associated with the population's aging process [15]. A 29\% increase in deaths from diabetes in North America, a 12\% increase in East Asia, and an 11\% increase in West Asia indicate a growing trend of deaths from diabetes [14], which is consistent with the results of the present study. Death from diabetes is mainly due to its complications such as cardiovascular diseases, kidney problems, and the like [16].
In this study, the number of deaths due to diabetes was significantly different between men and women, so that in all study years, deaths due to diabetes in women were significantly higher than in men. This finding is consistent with the findings of Ruiz-Ramos et al. in Spain [17] and Roglic [18]. The higher prevalence of diabetes in women can be one of the causes of high mortality due to diabetes in women [18]. In the study of Farahmand et al. [19], obesity has been reported as a risk factor for diabetes in women more than men, which is considered a risk factor in diabetes [12]. Another cause of obesity in women is related to childbirth [20, 21]. Gharipour study [22] states that people with a BMI above 30 are 9.98 times more likely to develop diabetes, which all justifies the causes of more deaths in women, according to the present study results.

The present study showed that the mortality rate from various types of diabetes in all years in urban areas was much higher than that in rural areas. This finding was inconsistent with the results of a study by Bragg et al. in China, which showed that despite the higher prevalence of diabetes in urban areas, more deaths occur in rural areas. They blamed the lack of diabetes management and its complications in rural areas [23].

Increased urbanization $[19,24]$, change in lifestyle pattern, a tendency to western life [25], and dietary style and tendency to consume ready-to-eat, fast foods and sedentary [26] during the last two decades, especially in developing countries, are some of the reasons for the higher prevalence of diabetes and consequent death from diabetes in urban areas. Behaviors and lifestyles strongly influence non-communicable diseases. The victims of these diseases share an unhealthy diet with high saturated fat and sugar, low physical activity, and smoking. The high prevalence of diabetes in cities can also be due to low physical activity and high consumption of sugar and fatty foods that are risk factors for

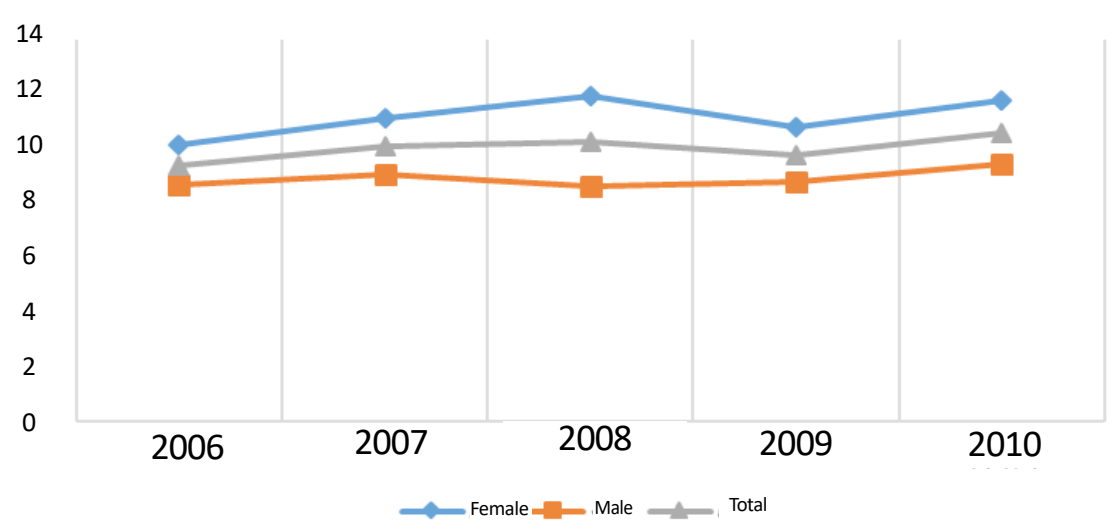

Figure 1. Mortality rate due to diabetes per 100000 population by sex 


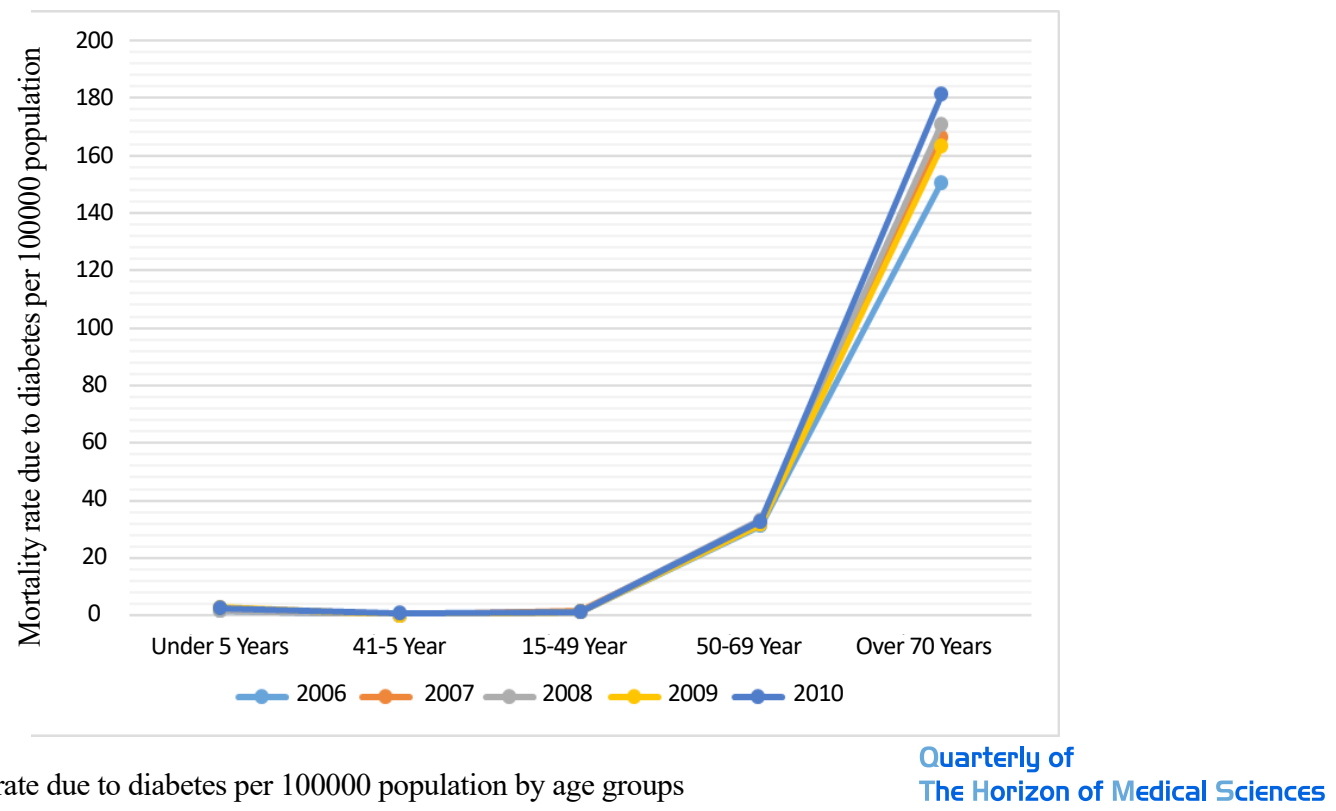

Figure 2. Mortality rate due to diabetes per 100000 population by age groups

Quarterly of

diabetes. These foods become synonymous with the urban lifestyle. On the contrary, its prevalence in rural areas has remained low due to limited exposure to risk factors and rural life preservation, and traditional physical activity [27].

In the present study, the lowest death rate from diabetes belonged to the age group of 5-14 years, and the highest rate was seen in people over 70 years. After the age group of under 5 years, a relative decrease in the death rate is observed in the age group 5 to 14 years. Then, the death rate of diabetes has increased with age and has risen vertically in 70 years and above. Bragg et al. reported that the prevalence of diabetes also increased with age [23]. In 2010, nearly 4 million people were estimated to die of diabetes, about $6.5 \%$ of the total number of deaths at all ages, and $10 \%$ of all deaths between the ages of 20-79 years [18].
This study showed that the highest cause of death was non-insulin-dependent diabetes, with $40 \%$ of all deaths. The prevalence of diabetes in Iran is high and is expected to increase in the future, along with increasing life expectancy, urban development, and increasing obesity. Preventive activities in controlling diabetes and thus reducing its mortality can be done in different ways. Before employing any prevention policies, much benefit can be obtained from the effects of increasing awareness about diabetes in the general population. Many studies have reported a lack of knowledge about diabetes and its risk factors in South Asia $[28,29]$ and even in patients with diabetes [30, 31]. Diabetes has many risk factors that can be changed with lifestyle and by promoting knowledge in this field, adopt a healthy lifestyle. Mohan et al. [32] reported that in an Indian community, creating a public park at one's own expense significantly increased the physical activity of local residents.

Table 2. Mortality rate due to diabetes per 100000 population by sex, age $\mathrm{p}$, and place of residence

\begin{tabular}{|c|c|c|c|c|c|c|c|c|c|c|c|c|c|c|c|}
\hline \multirow{2}{*}{ Year } & \multicolumn{3}{|c|}{ Under 5 Years } & \multicolumn{3}{|c|}{ 5-14 Year } & \multicolumn{3}{|c|}{ 15-49 Year } & \multicolumn{3}{|c|}{ 50-69 Year } & \multicolumn{3}{|c|}{ Over 70 Years } \\
\hline & Female & Male & Total & Female & Male & Total & Female & Male & Total & Female & Male & Total & Female & Male & Total \\
\hline 2006 & 1.66 & 1.94 & 1.81 & 0.22 & 0.14 & 0.18 & 1.23 & 1.47 & 1.35 & 33.30 & 29.56 & 31.44 & 175.65 & 128.94 & 150.69 \\
\hline 2007 & 2.18 & 3.00 & 2.60 & 0.13 & 0.15 & 0.14 & 1.41 & 1.60 & 1.51 & 34.64 & 29.85 & 32.28 & 199.80 & 137.73 & 166.38 \\
\hline 2008 & 1.42 & 2.03 & 1.73 & 0.26 & 0.08 & 0.15 & 1.50 & 1.34 & 1.42 & 37.11 & 29.53 & 33.38 & 212.28 & 134.07 & 170.99 \\
\hline 2009 & 3.12 & 2.73 & 2.94 & 0.23 & 0.13 & 0.18 & 1.23 & 1.37 & 1.30 & 34.63 & 28.83 & 31.78 & 188.17 & 140.46 & 163.18 \\
\hline 2010 & 2.62 & 2.57 & 2.59 & 0.34 & 0.14 & 0.24 & 1.45 & 1.40 & 1.42 & 34.34 & 31.52 & 32.95 & 214.52 & 150.61 & 181.31 \\
\hline
\end{tabular}


Table 3. Number and rate of deaths by type of diabetes per 100000 population by sex

\begin{tabular}{|c|c|c|c|c|c|c|c|}
\hline \multirow{2}{*}{ Year } & \multirow{2}{*}{ Type of Diabetes (ICD-10 Code) } & \multicolumn{3}{|c|}{ Frequency } & \multicolumn{3}{|c|}{ The Rate per 100000} \\
\hline & & Female & Male & Total & Female & Male & Total \\
\hline \multirow{3}{*}{2006} & Insulin-dependent diabetes (E10) & 737 & 667 & 1404 & 2.62 & 2.30 & 2.46 \\
\hline & Non-insulin dependent diabetes (E11) & 1236 & 1130 & 2366 & 4.40 & 3.9 & 4.14 \\
\hline & Other diabetic disorders (E12-E14) & 885 & 720 & 1605 & 3.15 & 2.49 & 2.81 \\
\hline \multirow{3}{*}{2007} & Insulin-dependent diabetes (E10) & 898 & 697 & 1595 & 3.43 & 2.59 & 3.01 \\
\hline & Non-insulin dependent diabetes (E11) & 1224 & 1064 & 2288 & 4.68 & 3.96 & 4.31 \\
\hline & Other diabetic disorders (E12-E14) & 798 & 671 & 1469 & 3.05 & 2.50 & 2.77 \\
\hline \multirow{3}{*}{2008} & Insulin-dependent diabetes (E10) & 827 & 678 & 1505 & 3.12 & 2.49 & 2.80 \\
\hline & Non-insulin dependent diabetes (E11) & 1276 & 946 & 2222 & 4.81 & 3.48 & 4.14 \\
\hline & Other diabetic disorders (E12-E14) & 1060 & 730 & 1790 & 4.00 & 2.69 & 3.43 \\
\hline \multirow{3}{*}{2009} & Insulin-dependent diabetes (E10) & 792 & 756 & 1548 & 2.95 & 2.75 & 2.85 \\
\hline & Non-insulin dependent diabetes (E11) & 1122 & 893 & 2015 & 4.18 & 3.24 & 3.70 \\
\hline & Other diabetic disorders (E12-E14) & 984 & 779 & 1763 & 3.66 & 2.83 & 3.24 \\
\hline \multirow{3}{*}{2010} & Insulin-dependent diabetes (E10) & 1050 & 896 & 1946 & 3.85 & 3.21 & 3.53 \\
\hline & Non-insulin dependent diabetes (E11) & 1142 & 933 & 2075 & 4.19 & 3.34 & 3.76 \\
\hline & Other diabetic disorders (E12-E14) & 1022 & 805 & 1827 & 3.75 & 2.88 & 3.31 \\
\hline \multirow{3}{*}{ Total } & Insulin-dependent diabetes (E10) & 4303 & 3694 & 7998 & 15.97 & 13.35 & 14.64 \\
\hline & Non-insulin dependent diabetes (E11) & 6000 & 4966 & 10966 & 22.25 & 17.98 & 20.06 \\
\hline & Other diabetic disorders (E12-E14) & 4749 & 3705 & 8454 & 17.61 & 13.39 & 15.47 \\
\hline
\end{tabular}

Leaving the traditional food patterns and consuming diets high in saturated fat and refined carbohydrates are essential factors in increasing obesity and diabetes. Consumption of low amounts of fiber and unsaturated fats, as well as high intake of refined carbohydrates, saturated fats, and trans fats, are among the diets that lead to insulin resistance and diabetes [33]. Therefore, policies should focus on informing and educating on these unhealthy eating patterns. Other successful policies in this area include efforts to improve food labels and to train to reduce the incidence of diabetes and obesity.

Today, the aging of the population is observed in developing countries, and especially in these countries, geographical transmission occurs on a larger scale without improving living conditions, social provision, and access to health care. It is predicted that with unhealthy aging due to lack of progress in nutritional status and socio-economic conditions, the disease's burden will increase in the elderly population. Thus, it is essential to consider both prevention and treatment policy options. Also, in non-communicable diseases, the underlying causes should be considered, and the health system's capacities to deal with the increasing burden of the disease should be examined.

\section{Conclusion}

From 2006 to 2010, deaths due to diabetes have increased in Iran, and it was higher in women and urban communities. Because of the increase in the elderly population, the growing trend of urbanization, changing diet and lifestyle in Iran, it is necessary to plan, educate, and perform interventions to prevent, diagnose, and early treatment of diabetes. 


\section{Ethical Considerations}

\section{Compliance with ethical guidelines}

In this study, the data published by the Ministry of Health and Medical Education of Iran has been used and publishers have maintained the confidentiality of the data.

\section{Funding}

This research did not receive any grant from funding agencies in the public, commercial, or non-profit sectors.

Authors' contributions

Investigation, writing - original draft, and writing - review \& editing: All Authors; Methodology, data collection and data analysis: Amin Ataey.

\section{Conflicts of interest}

The authors declared no conflict of interest.

\section{Acknowledgements}

We would like to thank all the people who helped us in compiling this article. Also, we used the information published by the Deputy Minister of Health of the Ministry of Health. So we appreciate the efforts of these colleagues. 
This Page Intentionally Left Blank 


\title{
ايبدميولورى و روند مرتى به دليل ديابت در ايران
}

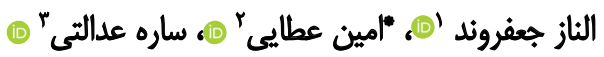



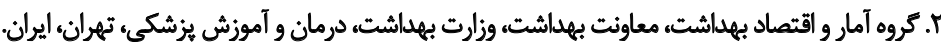

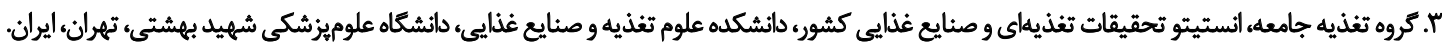

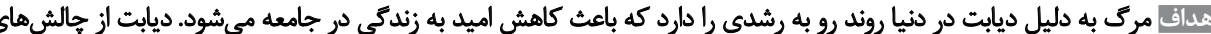

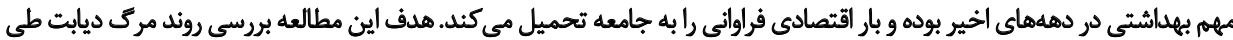

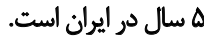

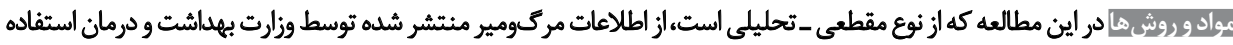

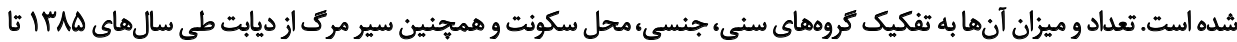

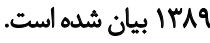



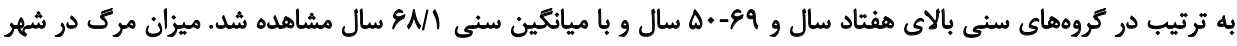

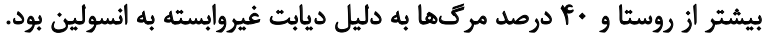

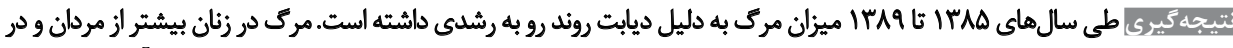

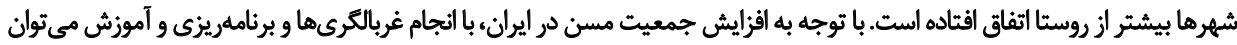



خواهد رسيد. اين افزايش در كشورهاى در حال توسعه معادل

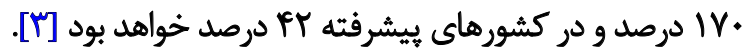

dotô

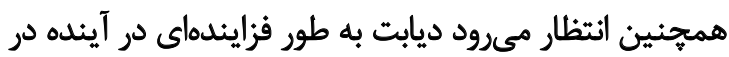

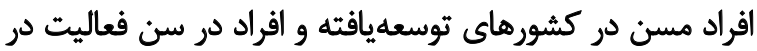

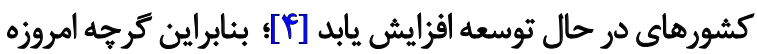

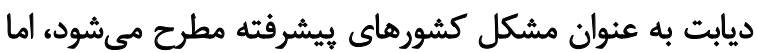

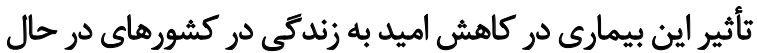

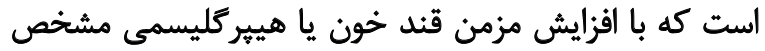
مىشود و ناشى از اختلال ترشح يا عمل انسولين و يا هي هر دوى مئي

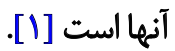
ديابت يكى از قالشهاى بهداشتى دهلهاى اخير است كه

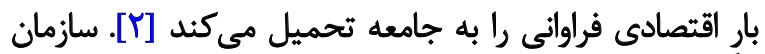


صاحبنظران عقيده دارند كه شيوع اخير ديابت در جامعه

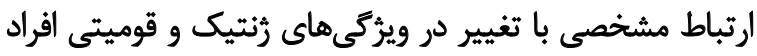

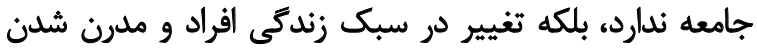

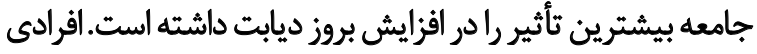

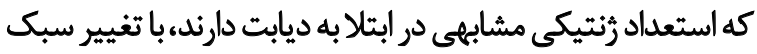


بو 199 تمام كشورهاى جهان را به مقابله با اين اييدمى فراخواند.

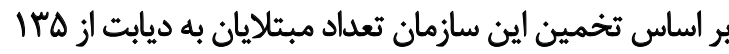




بيمارستانها و خانههاى بهداشت از سوى مركز اطلاعات و

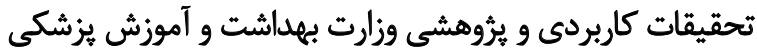

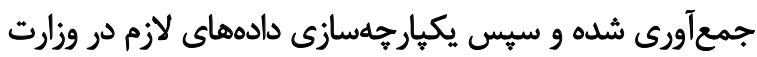
بهداشت، درمان و آموزش بزئشكى انجام شده است. در مطالعه حاضر، دادههاي مربوط به مركومير ناشى از انواع

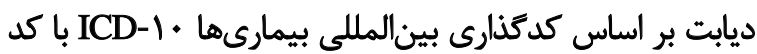





تعداد و ميزان مركى ناشى از ديابت، نسبت جنسى مرد به

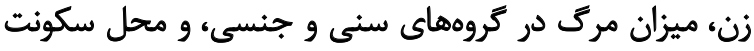



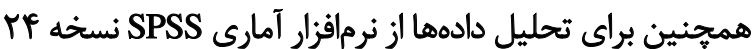



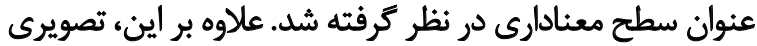

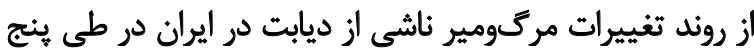

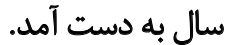

ياقتثلها

در اين مطالعه، تمام دادههاى مربوط به مرك انواع ديابت از



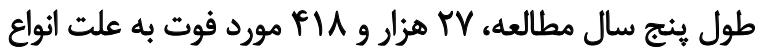



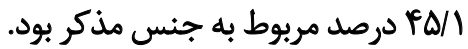

از سويى كمترين ميزان فوت در مجموع هر دو جنس در سال IFAD

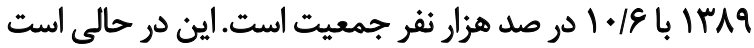



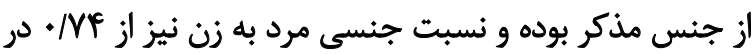

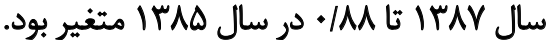

زندكى شان ميزان شيوع ابتلا به ديابت تغيير مى كند [\&].

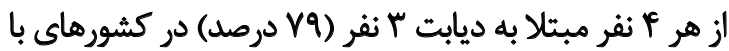

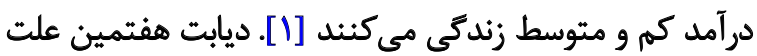

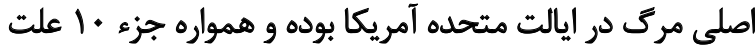


همجنين در مطالعاى در شش كشور از جمله بحرين، كره

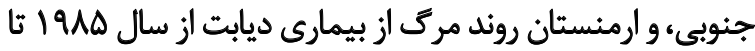

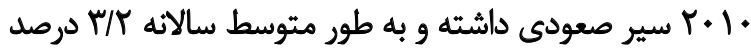

افزايش داشته است [ᄉ]].

آكاهى از اطلاعات مربوط به تعداد و علل فوت براى تشخيص



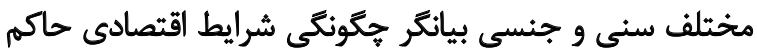

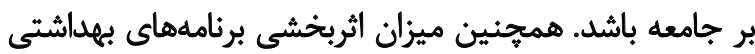



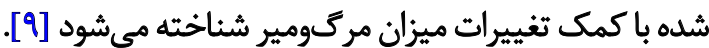

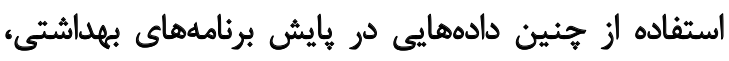

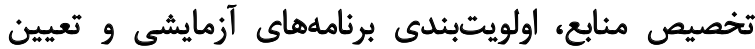





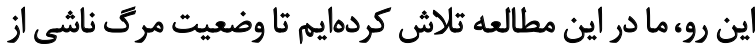


آن را بررسى كنيه.

مواد وروشها نها

اين مطالعه به صورت مقطعى ـ تحليلى با استفاده از دادههاى



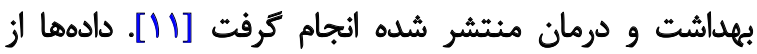
طريق منابع مختلف، از جمله سازمان ثبت احوال، كورستانها،

جدول ا. تعداد و ميزان مرك به علت ديابت در هر .1 هزار نفر جمعيت به تفكيك جنس و محل سكونت

\begin{tabular}{|c|c|c|c|c|c|c|c|c|c|c|}
\hline \multirow{2}{*}{ سنى (سال) ميني } & \multicolumn{2}{|c|}{ (ميزان در + اكونت هزار) } & \multirow{2}{*}{ نسبت جنسى (مرد/زن) } & \multicolumn{3}{|c|}{ ميزان در صد هزار } & \multicolumn{3}{|c|}{ تعداد (دوصد) } & \multirow{2}{*}{ سال } \\
\hline & شهر & ا روستا & & 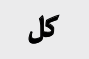 & مرد & j & 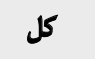 & مرد & زن & \\
\hline EV/V & $1.1 . v$ & $\Delta / 91$ & $\cdot \mid M$ & T/Fr & NEq & $1 . / 1 \mathrm{~V}$ & ArVA & roIV (E\&/A) & $\mathrm{rA \Delta A}(\Delta T / Y)$ & ITAD \\
\hline$e q / r^{2}$ & $11 / \cdot r$ & g/Mr & . /Ar & 1.1 .9 & $9 / .0$ & $11 / 10$ & QTUY & $\operatorname{MeTr}\left(f \Delta / f^{e}\right)$ & rqY.(Ar/g) & ITN \\
\hline ENA & $\mid 1 / 4$ & $8 / M$ & $\cdot M$ & $1.1 . r$ & NeP & $11 / 94$ & $\Delta Q I V$ & $\operatorname{rTaf}(E T / M)$ & 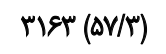 & ITAY \\
\hline \&A & 1.18 & g/gr & - IAF & $9 / 79$ & NAY & $1 . / 199$ & AMre & TPTA (FA/F) & rАน $(\Delta \% / \%)$ & IrM \\
\hline eq/8 & $11 / 8$ & $9 / 94$ & - /AY & 1.18 & $9 / p$ & $11 / 2 \wedge$ & DAFA & reme $(f \Delta)$ & MTIF (DQ) & 1r^a \\
\hline gN & & & . /AY & & & & meis & 1 Mrea $(F \Delta / 1)$ & $1 \Delta \cdot \Delta r\left(\Delta T^{r} / q\right)$ & مجموع \\
\hline
\end{tabular}

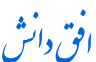




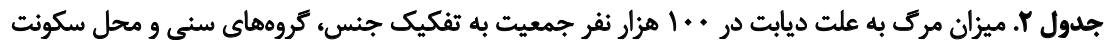

\begin{tabular}{|c|c|c|c|c|c|c|c|c|c|c|c|c|c|c|c|}
\hline \multicolumn{3}{|c|}{ بالاى • سال } & \multicolumn{3}{|c|}{ 97- +0 سال } & \multicolumn{3}{|c|}{ 9-10 سال } & \multicolumn{3}{|c|}{ 1E-0 سال } & \multicolumn{3}{|c|}{ زير ه سال } & \multirow{2}{*}{ سال } \\
\hline كل & مرد & زن & كل & مرد & زن & كل & مرد & نj & كل & مرد & زن & ل & مرد & زن & \\
\hline $10 \cdot 189$ & IYNAF & IVA/ED &  & $r Q / \Delta S$ & $\pi / r$. & ו/Tם & V/PV & س & .111 &.$/ 14$ &.$/ \pi r$ & $\mid / A 1$ & $1 / 94$ & $1 / 98$ & ITNA \\
\hline IEg/TA & $I F / M^{m}$ & 192/1. & MT/TA & rQAa & $M e / g e$ & $V / \Delta \mid$ & V/E. & $V / F i$ & $.11)^{\circ}$ &.$/ 10$ & ./N & $r / 8$. & $\mathrm{m} /$. & $Y / M$ & $1 \mathrm{HN}$ \\
\hline $17 . / 99$ & $\mid m e / \cdot v$ & TIYRA & גו & TQ/AT & $r V / M$ & I/FT & $1 / m$ & V/a. & .110 & $.1 \cdot 1$ &.$/ 48$ & $1 / r^{\prime \prime}$ & $M / \cdot H$ & I/Fr & ITAV \\
\hline $\mid E T / 1 \mathrm{~A}$ & $1 f \cdot 178$ & IMIV & rI/vi & TNAT & $M \in / g r$ & $1 / r$. & $1 / m V$ & $1 / \pi$ &.$/ 11$ &.$/ N r$ &.$/ \pi$ & r/qf & $r / V A$ & $r / M r$ & ITM \\
\hline$|A| /{ }^{\prime} \mid$ & $|0+| 8 \mid$ & rif/ar & rT/QA & MVIAT & $M e / N F$ & I/Fr & $1 / 4$ & $v / F \Delta$ &.$/ M F$ &.$/ 1 F$ &.$/ M f$ & $r / \Delta q$ & $\mathrm{r} / \Delta \mathrm{V}$ & T/AT & 17199 \\
\hline
\end{tabular}

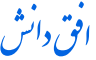



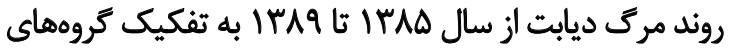

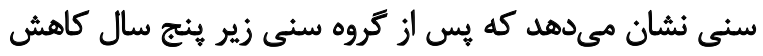

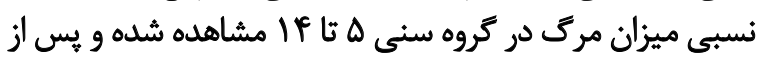

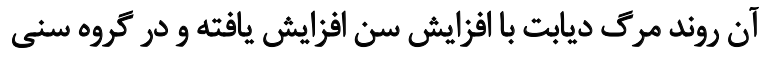

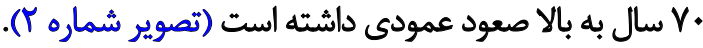

در بررسى مرك ناشي از ديابت به تفكيك نوع آن طى هينج



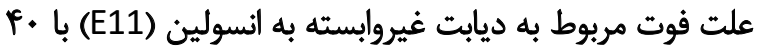

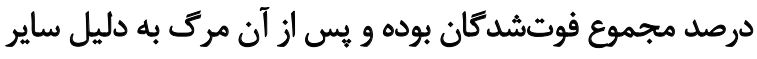

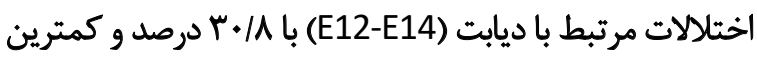





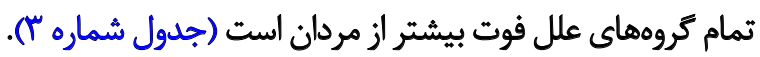
ديابت در مناطق شهرى بيشتر از مناطق روستايي است. ميانكين



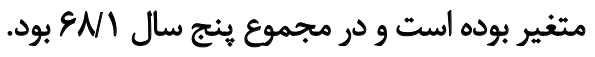

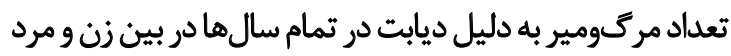

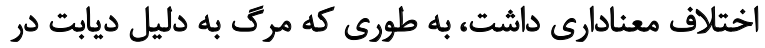

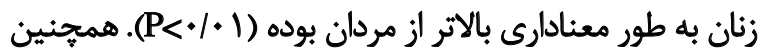

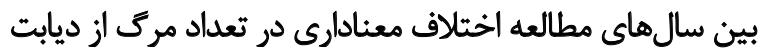


روند افزايشى داشته است (جدول شماره إنه إو تصوير شماره ()).

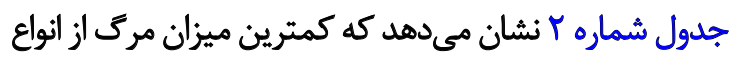

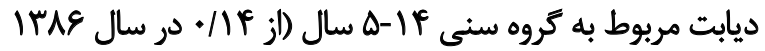

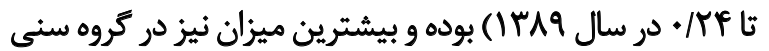






جدول r. تعداد و ميزان مرك به تفكيك نوع ديابت در هر صد هزار نفر جمعيت به تفكيك جنس

\begin{tabular}{|c|c|c|c|c|c|c|c|}
\hline \multicolumn{3}{|c|}{ ميزان در ••ا هزار } & \multicolumn{3}{|c|}{ فراوانى } & \multirow{2}{*}{ نوع ديابت (كد)1CD-10) } & \multirow{2}{*}{  } \\
\hline كل & 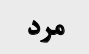 & زن & كل &  & 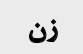 & & \\
\hline t/Re & $r / r \cdot$ & rfar & if $+f$ & egr & $n v$ & ديابت وابسته به اثسولين (E10) & \\
\hline$\varphi / l f$ & $r / q$ & $p / t$ & mese & $11 \mathrm{r}$. & IMre & ديابت غيروابسته به انسولين (E11) & IrNA \\
\hline$r / A)$ & $r / e q$ & $r / 10$ & $19 \cdot \Delta$ & $r$ & MA & ساير اختلالات مربوط به ديابت (E14-E12) & \\
\hline$r / \infty 1$ & $r / \Delta q$ & $r / e r$ & 1090 & eqr & 14 & ديابت وابسته به انسولين (E10) & \\
\hline$\varphi / m$ & $r / Q$ & flen & TYM & 1.94 & irre & ديابت غيروابسته به انسولين (E11) & IrNe \\
\hline$r / W$ & $r / \Delta$. & $r / \circ \Delta$ & lfeq & sn & vau & ساير اختلالات مربوط به ديابت (E14-E12) & \\
\hline$r / \Lambda$. & $r / 2 q$ & r/Mr & $10 \cdot \Delta$ & gra & ATY & ديابت وابسته به اتسولين (E10) & \\
\hline f/lf & $m / \& A$ & $F(A)$ & MTM & 948 & irve & ديابت غيروابسته به انسولين (E11) & IrAY \\
\hline$r / \mu r$ & r/qq & 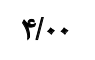 & iva. & $n^{n}+$ & 1.9. & ساير اختلالات مربوط به ديابت (E14-E14) & \\
\hline r/AS & r/Va & $r / q \Delta$ & IAFA & VAS & var & ديابت وابسته به انسولين (E10) & \\
\hline$r / v$ & $r / T F$ & $F / M$ & $r+10$ & 194 & IIrr & ديابت غيروابسته به انسولين (E11) & IrM \\
\hline$r / r^{e}$ & $r / A r$ & rige & IVeT & $m 9$ & Q⿱乛龰 & ساير اختلالات مربوط به ديابت (E14-E12) & \\
\hline$r / \Delta r$ & $M / M$ & W/Aa & 1948 & 198 & $1+\Delta$ & ديابت وابسته به انسولين (E10) & \\
\hline$r / v q$ & $m / m e$ & $8 / 19$ & $r \cdot V \Delta$ & am & IIfT & ديابت غيروابسته به انسولين (E11) & $1 \% 19$ \\
\hline$r / m$ & $r / M$ & r/Va & IArY & $A+\Delta$ & $1 . r+r$ & ساير اختلالات مريوط به ديابت (E12-E14) & \\
\hline lfige & $1 \% / r 5$ & $10 / 9 V$ & vaq & reqp & $\mu r+\mu$ & ديابت وابسته به ائسولين (E10) & \\
\hline$r .1 .9$ & IV/qu & Tr/TA & 1.988 & pres & q... & ديابت غيروابسته به انسولين (E11) & مجموع \\
\hline $10 / 4 \mathrm{~V}$ & $1 \% / \% 9$ & $|V| \& \mid$ & AFAF & $r v \cdot \Delta$ & preq & ساير اختلالات مربوط به ديابت (E14-E14) & \\
\hline
\end{tabular}

و روند بير شدن جمعيت ارتباط دارد [1ه].

بحث

افزايش و ج درصدى مرك به دليل ديابت در منطقه آمريكاى



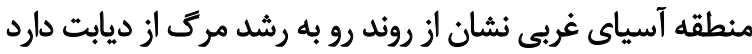



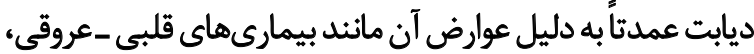
عوارض كليوى و غيره است [19].

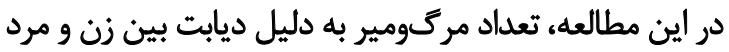



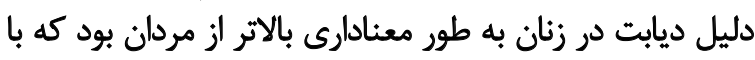



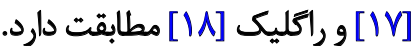
شيوع بيشتر بيمارى ديابت در زنان مىتواند يكى از دلايل
نتايج مطالعه حاضر در طول ينج سال نشان مي دهد كه به روند

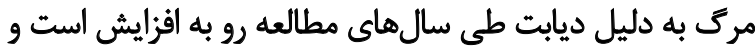

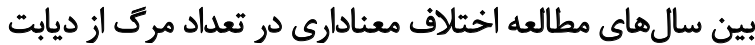

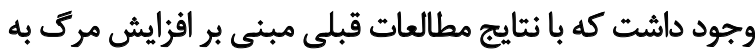

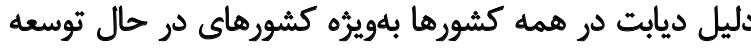

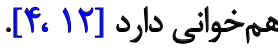



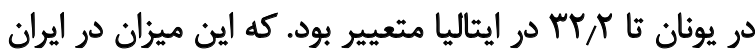

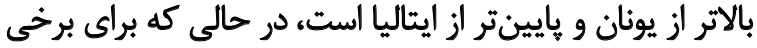

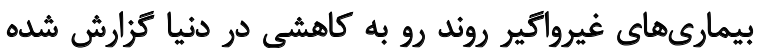

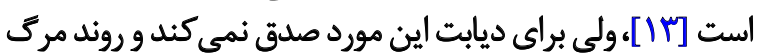

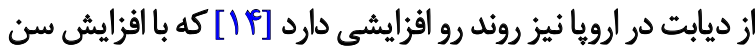








بالاي جربي اشباع و قند، يايين بودن فعاليت فيزيكى و مصرف دخانيات است

بالا بودن شيوع ديابت در شهرها ميثواند به دليل هيايين









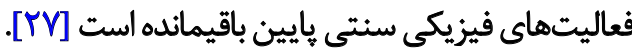
در مطالعه حاضر، كمترين ميزان مرك از ديابت مربوط به كروه

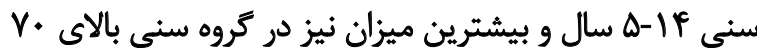

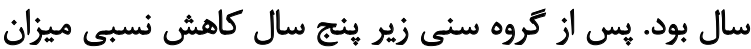

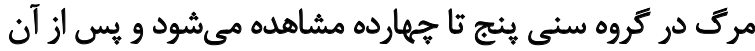

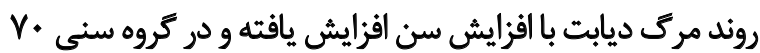
سال به بالا صعود عمودى داشته أست.

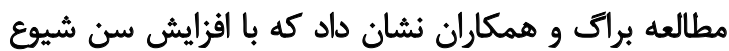

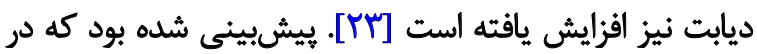

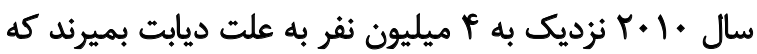

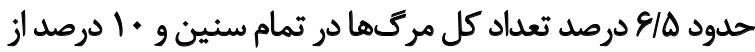

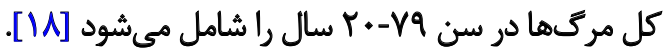
اين يُروهش نشان داد كه بيشُترين علت فوت مربوط به ديابت

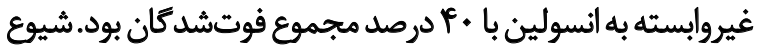

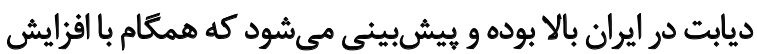

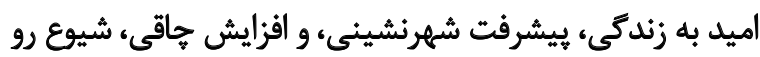

تصوير r. ميزان مرك به علت ديابت در صد هزار نفر جمعيت به تفكيك كروههاى سنى مرك بالا به علت ديابت در زنان باشد [1A]. در مطالعه فرهمند



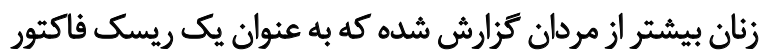

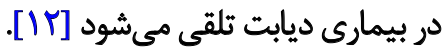

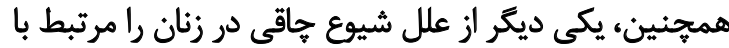





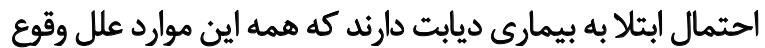

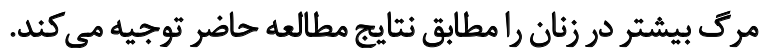
مطالعه حاضر نشان داد كه ميزان مرك از انواع ديابت در تمام

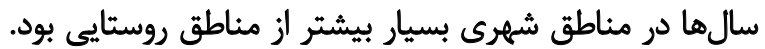

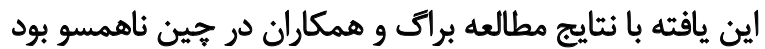

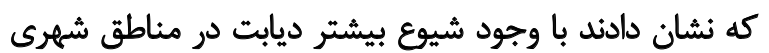

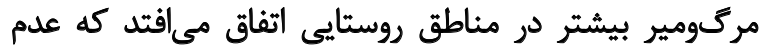

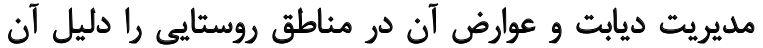

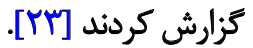



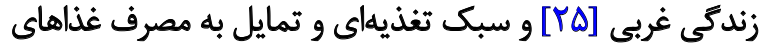



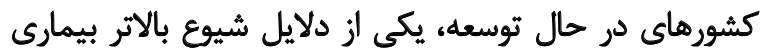
ديابت و درنتيجه مرى از بيمارى ديابت در مناطق شهرى دئ است.

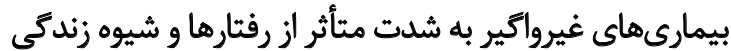






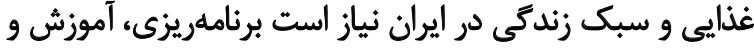

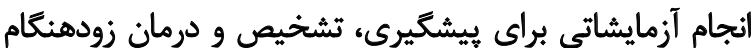

ديابت صورت كيرد.

ملاحظات اخلاقى

\section{يميروى أز الصول الخالاق يثوهش}

در اين مطالعه از اطلاعات منتشر شده وزارت بهداشت، درمان

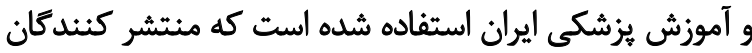

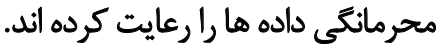



اين تحقيق هيج كونه كمك مالى از سازمانهاي تأمين مالى در بخشهاى عمومى ، تجارى يا غيرانتفاعى دريافت نكرد.

مشار كت نويسند مكان

بررسى، نوشتن مقاله اوليه، ويرايش و الصلاحات: همه نويسندكان؛ روش شناسى، جمعآورى و آناليز دادهها: امين اصلين عطايى.

\section{ت تعارض مثافع}

هيج كونه تعارض منافع توسط نويسندكان مقاله بيان نشده



در تدوين اين مقاله از اطلاعات منتشرشده توسط معاونت

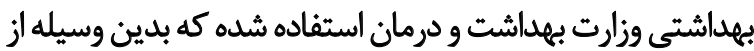
زحمات اين همكاران قدردانى به عمل مي آيد.

$$
\text { به رشدى در آينده داشته باشد. }
$$

فعاليتهاى بيشگيرانه در كنترل ديابت و درنتيجه كاهش

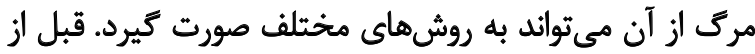

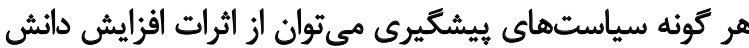

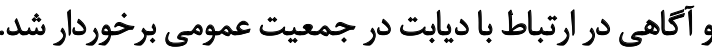

خسيارى از مطالعات، عدم وجود آكاهى در مورد ديابت و عوامل

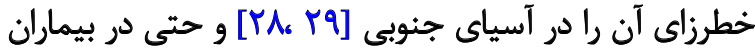

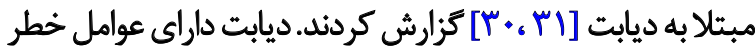

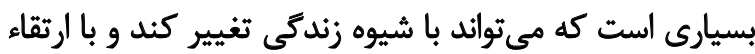
دانش در اين زمينه شيوه زندكى سالمى را اتخاذ كردي.




ملاحظهاى در ميزان فعاليت فيزيك ساكنين محلى شداند. خروج از الكوهاى غذاى سنتى ودريافت رزيمهاى غذايى باجربى بإيى



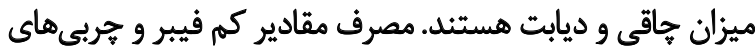

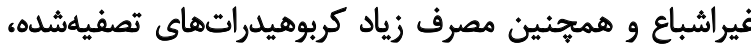





بنابراين سياستها بايد به اطلاعرسانى و آموزش روى اين



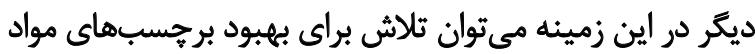

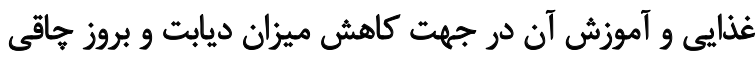



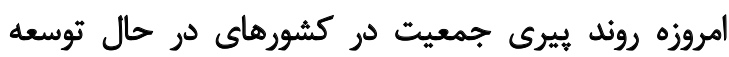

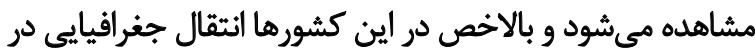

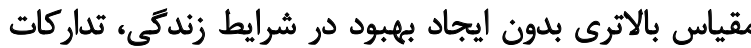

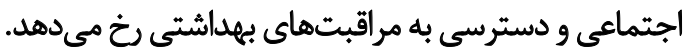
ييشبينى مىشود با بيرى ناسالم به دليل عدم پيشرفت در

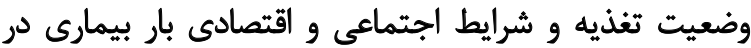

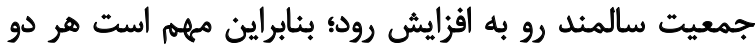



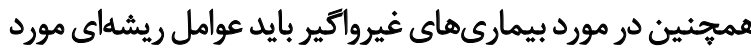

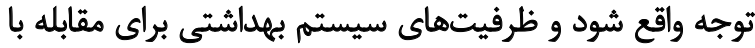
افزايش بار بيمارى بروسى شوند.

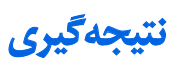



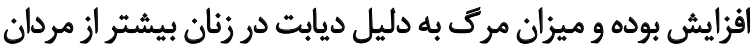



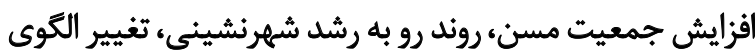




\section{References}

[1] International Diabetes Federation. IDF Diabetes Atlas [Internet]. 2019 [Updated 2019]. Available from: https://www.diabetesatlas.org/en/ resources/

[2] Maracy MR, Kheirabadi GR, Fakhari N, Zonnari R. [Comparison of night time sleep quality in type 2 diabetics, impaired glucose tolerance cases and non-diabetics (Persian)]. Iranian Journal of Endocrinology and Metabolism. 2011; 13(2):165-72. http://ijem.sbmu.ac.ir/article-1-1099-en. html.

[3] Azizi F, Hatami H, Janghorbani M. [Epidemiology and control of common diseases in Iran (Persian)]. $1^{\text {th }}$ ed. Tehran: Eshtiagh Publicatio; 2007.

[4] Boyle JP, Thompson TJ, Gregg EW, Barker LE, Williamson DF. Projection of the year 2050 burden of diabetes in the US adult population: Dynamic modeling of incidence, mortality, and prediabetes prevalence. Population Health Metrics 2010; 8:29. [DOI:10.1186/1478-7954-8-29] [PMID] [PMCID]

[5] Roglic G, Unwin N, Bennett PH, Mathers C, Tuomilehto J, Nag S, et al. The burden of mortality attributable to diabetes. Diabetes Care. 2005; 28(9):2130-5. [DOI:10.2337/diacare.28.9.2130] [PMID]

[6] Joshi SK, Shrestha S. Diabetes mellitus: A review of its associations with different environmental factors. Kathmandu University Medical Journal. 2010; 8(29):109-15 [DOI:10.3126/kumj.v8i1.3233] [PMID]

[7] Heron MP. Deaths: leading causes for 2012. National Vital Statistics Reports. 2015; 64(10):1-93. [PMID]

[8] Malaki Moghadam H, Askarishahi M. [Trend analysis of mortality rate due to diabetes mellitus in seven countries of Asia between 1985-2010: A joinpoint regression analysis (Persian)]. Iranian Journal of Endocrinology and Metabolism. 2017; 18(6):412-9. http://ijem.sbmu.ac.ir/article1-2111-fa.html

[9] Naghavi M, Jafari N. [Mortality in 29 provinces of the country in 2004 (Persian)]. Tehran: Arvij; 2007. http://opac.nlai.ir/opac-prod/bibliographic/1028108

[10] Dortag E, Bahrampour A, Haghdost A, Zendedel K, Jaberipour M, Marzeban $\mathrm{M}$. [Completeness of fars province deaths registry on cancer death using capture recaptures method (Persian)]. Journal of North Khorasan University of Medical Sciences. 2011; 3(5):33-44. [DOI:10.29252/ jnkums.3.5.S5.33]

[11] Khosravi A, Aghamohamadi S, Kazemi E, Pour Malek F, Shariati M. Mortality profile in Iran (29 provinces) over the years 2006 to 2010 . Tehran: Ministry of Health and Medical Education; 2013.

[12] Hajer GR, van Haeften TW, Visseren FL. Adipose tissue dysfunction in obesity, diabetes, and vascular diseases. European Heart Journal. 2008; 29(24):2959-71. [DOI:10.1093/eurheartj/ehn387] [PMID]

[13] Tunstall-Pedoe H, Kuulasmaa K, Mahonen M, Tolonen H, Ruokokoski E, Amouyel P. Contribution of trends in survival and coronar y-event rates to changes in coronary heart disease mortality: 10-year results from 37 WHO MONICA Project populations. Lancet (London, England). 1999; 353(9164):1547-57. [DOI:10.1016/S0140-6736(99)04021-0]

[14] World Diabetes Foundation. Diabetes Atlas, $3^{\text {rd }}$ edition WDF04-084 [Internet]. 2006 [Updated 2006]. Available from: https://www.worlddiabetesfoundation.org/projects/belgium-wdf04-084

[15] Garcia BF, Godoy C, Perez S, Bolumar F. Multiple codification of the causes of death: From dying" of" to dying" from". Gaceta Sanitaria. 1992; 6(29):53-7. [DOI:10.1016/S0213-9111(92)71092-9]
[16] Goldacre MJ. Cause-specific mortality: Understanding uncertain tips of the disease iceberg. Journal of Epidemiology and Community Health. 1993; 47(6):491-6. [DOI:10.1136/jech.47.6.491] [PMID] [PMCID]

[17] Ruiz-Ramos M, Escolar-Pujolar A, Mayoral-Sanchez E, Corral-San Laureano F, Fernandez-Fernandez I. Diabetes mellitus in Spain Death rates, prevalence, impact, costs and inequalities. Gaceta Sanitaria. 2006; 20(S1):15-24. [DOI:10.1157/13086022] [PMID]

[18] Roglic G, Unwin N. Mortality attributable to diabetes: Estimates for the year 2010. Diabetes Research and Clinical Practice. 2010 87(1):15-9. [DOI:10.1016/j.diabres.2009.10.006] [PMID]

[19] Farahmand M, Hejazi N, Akbarzade M, Almasi-Hashiani A. [Prevalence of obesity in urban and rural population of Fars province, national plan of chronic disease risk factor surveillance, (2006-07) (Persian)]. Zahedan Journal of Research in Medical Sciences. 2012; 13(S1):49. https://sites.kowsarpub.com/zjrms/articles/95265.html

[20] Hajian K, Hiedari B. [Prevalence of abdominal obesity in a population aged 20 to 70 years in urban Mazandaran (northeran Iran, 2004) (Persian)]. Iranian Journal of Endocrinology and Metabolism. 2006; 8(2):147-56. http://ijem.sbmu.ac.ir/article-1-282-en.htm

[21] Sarshar N, Khajavi AJ. [The prevalence of obesity in females of 1565 years of age in Gonabad, Iran (Persian)]. The Horizon of Medical Sciences. 2006; 12(3):38-43. http://hms.gmu.ac.ir/article-1-65-en. html

[22] Gharipour M, Mohammadifard N, Asgsri S, Naderi G. [The prevalence of obesity and cardiovascular risk factors in Isfahan (Persian)] Journal of Inflammatory Disease. 2003; 7(2):53-64. http://journal. qums.ac.ir/article-1-242-en.htm

[23] Bragg F HM, lona A, Guo Y, Du H, Chen Y, Bian Z, et al. Association between diabetes and cause-specific mortality in rural and urban areas of China. JAMA. 2017; 317(3):280-9. [DOI:10.1001/ jama.2016.19720] [PMID] [PMCID]

[24] Okosun IS, Chandra KD, Boev A, Boltri JM, Choi ST, Parish DC, et al. Abdominal adiposity in U.S. adults: Prevalence and trends, 19602000. Preventive Medicine. 2004; 39(1):197-206. [DOI:10.1016/j. ypmed.2004.01.023] [PMID]

[25] Ghassemi H, Harrison G, Mohammad K. An accelerated nutrition transition in Iran. Public Health Nutrition. 2002; 5(1a):149-55 [DOI:10.1079/PHN2001287] [PMID]

[26] Kelishadi R, Ardalan G, Gheiratmand R, Gouya MM, Razaghi EM, Delavari $A$, et al. Association of physical activity and dietary behaviours in relation to the body mass index in a national sample of Iranian children and adolescents: CASPIAN Study. Bulletin of the World Health Organization. 2007; 85:19-26. [DOI:10.2471/BLT.06.030783] [PMID] [PMCID]

[27] Cheema A, Adeloye D, Sidhu S, Sridhar D, Chan KY. Urbanization and prevalence of type 2 diabetes in Southern Asia: A systematic analysis. Journal of Global Health. 2014; 4(1):010404. [DOI:10.7189/ jogh.04.010404] [PMID] [PMCID]

[28] Rafique G, Azam S, White F. Diabetes knowledge, beliefs and practices among people with diabetes attending a university hospita in Karachi, Pakistan. Eastern Mediterranean Health Journal. 2006; 12(5):590-8. [PMID]

[29] Ulvi OS, Chaudhary RY, Ali T, Alvi RA, Khan M, Khan M, et al. Investigating the awareness level about diabetes mellitus and associated factors in Tarlai (rural Islamabad). Journal of Pakistan Medical Association. 2009; 59(11):798-801. [PMID] 
[30] Murugesan N, Snehalatha C, Shobhana R, Roglic G, Ramachandran A. Awareness about diabetes and its complications in the general and diabetic population in a city in southern India. Diabetes Research and Clinical Practice. 2007; 77(3):433-7. [DOI:10.1016/j.diabres.2007.01.004] [PMID]

[31] Gul N. Knowledge, attitudes and practices of type 2 diabetic patients. Journal of Ayub Medical College Abbottabad. 2010; 22(3):128-31. [PMID]

[32] Mohan V, Shanthirani C, Deepa M, Datta M, Williams O, Deepa R. Community Empowerment-a successful model for prevention of noncommunicable diseases in India-the Chennai urban population study [CUPS-17]. Journal of the Association of Physicians of India. 2006; 54:858-62. [PMID]

[33] Misra A, Khurana L, Isharwal S, Bhardwaj S. South Asian diets and insulin resistance. British Journal of Nutrition. 2008; 101(4):465-73. [DOI:10.1017/S0007114508073649] [PMID] 
This Page Intentionally Left Blank 